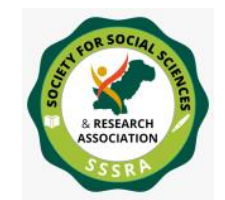

\title{
MILITARY AND POLITICS: A COMPARATIVE STUDY OF PAKISTAN AND TURKEY
}

\author{
Nawaz Ahmed \\ M.Phil. Scholar \\ Department of Political Science and International Relations \\ Istanbul Zaim University \\ Istanbul - Turkey \\ nawazahmed9922@gmail.com
}

\begin{abstract}
The history of Pakistan and Turkey has been marked by several common features with respect to the military's predominant role in politics. The Armed Forces in both the states many a time intervened in the politics either directly by toppling down the elected civilian governments or indirectly by forcing the elected popular governments to step down. In the history of the two countries, military has been playing a crucial role in the political arena, and it has been considered by majority of the society as the savior in uncertain situations like civil wars, political chaos and natural crisis in the country. In this paper, the author attempts to examine comparatively the causes of the military tutelage and dominancy in the politics in Turkey and Pakistan in a historical perspective. And in the second part, the author attempts to compare and contrast the similarities in the nature of the military's involvement in politics in both the states. In the last part of this paper, the author also discusses some common dissimilar features between the armed forces of the two countries with respect to their political role and suggests some measures to be taken to reduce the pre-dominant role of the military in the political arena.
\end{abstract}

Key Words: Military tutelage, Armed Forces, Pakistan, Turkey, Military Coup's

\section{Introduction}

The second half of twentieth century witnessed a rise in military coups in several states. Pakistan and Turkey were amongst the states that passed through this experience a couple of times in this period. The history of these two states has been marked by several common features with respect to the military's predominant role in politics. The armed forces in these two states time and again intervened in the politics either directly by 


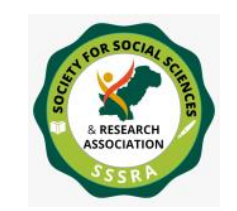

Military and Politics: A Comparative Study ...

toppling down the elected civilian governments or indirectly by forcing the elected popular governments to step down. In Pakistan, the military directly ruled the country by establishing military coup in 1958, 1977 and 1999 respectively. On the other hand, Turkish military directly intervened in the politics by overturning the civilian governments in 1960, 1971, and 1980 respectively. In the history of the two countries, military has been playing a crucial role in the political arena and it has been considered the final solution in the time of uncertain situations like civil wars, political chaos, and natural crisis by an overwhelming majority of the society. In this paper, the author attempts to examine comparatively the causes of the military tutelage and dominancy in the politics in Turkey and Pakistan in a historical perspective in detail and attempts to compare and contrast the similarities and differences in the nature of the military's involvement in politics in both the states. In the case of Pakistan, there are various causes which strengthened and provided confidence to the armed forces to take a dominant role. In this context, national security, weak political and democratic institutions, presence of an administrative vacuum, political disorder and chaos, massive foreign military assistance are some of the factors that boosted the confidence of the military and encouraged it to take a proactive role in the politics and act as a messiah in the time of political disorder and chaos.

On the other hand, history of Turkish military's involvement in politics projects a similar picture. The Turkish Armed Forces gained an upper hand in the politics by its historical role in the state-building process, its role as the founder and guardian of the republic, the guardian of the Kemalist principles of secularism, modernization and westernization, a barrier to the Islamic reactionaries and Kurdish separatism. Moreover, it has been regarded as the sole actor of modernization and westernization. Thus, it gained a massive public support from a massive segment of the society. Whenever the State basic Principles were imperiled, people looked upon the military for the salvation. In the last part of this paper, the author throws some light on some common as well as dissimilar features between the armed forces of the two countries with respect to their political role and suggests some measures to be taken to reduce the pre-dominant role of the military in the political arena.

\section{Military in the Politics of Pakistan: A Brief Background}

Since 1947, Pakistan has been ruled directly by military rulers three times. All three served as president for almost decades. The constitution was suspended, abrogated and the experiments were done with the forms of government and electoral system as well. General Muhammad Ayub Khan rose to power in 1958. On October 7, 1958, Iskander Mirza, the then president abrogated the first Constitution of the country, dismissed the central and provincial cabinets, dissolved the National and Provincial Assemblies, banned all political 


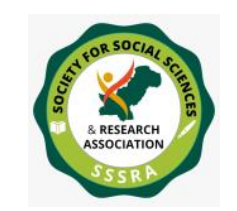

Military and Politics: A Comparative Study ...

parties in the country and declared martial law. The then chief of army General Ayub Khan was appointed the as the Chief Martial Law Administrator. General Ayub suspended the constitution and ensured that the new constitution gave him spacious powers. He made the country a staunch ally of the USA in the backdrop of Cold War bipolarity. Ayub Khan had to resign in 1969 because of protests in West Pakistan as well as the growing independence movement in what was then East Pakistan.

In 1977, General Muhammad Zia-ul-Haq seized power in a coup. Zulfikar Ali Bhutto, the ousted elected prime minister, was sentenced to death and executed in 1979. General Zia-ul-Haq promoted Islamization in the country and supported the Islamist fighters who were fighting the communist Red Army in Afghanistan with the help of the United States. He aligned the country more closely to Washington in the hot days of the Cold War. General Ziaul Haque died in 1988 in a plane crash thus ended one of the longest military regime in Pakistan.

The latest direct military rule started with the General Pervez Musharraf's toppling elected Prime Minister Nawaz Sharif in October 1999 just after when Sharif had decided to fire him as top army leader after a military campaign in the Kargil region of Kashmir (Rizvi, 2015, p. 149). Beside these direct military interventions, the military has indirectly intervened in politics time and again in the 1990s by forcing the civilian government of Nawaz Sharif and Benazir Bhutto to resign. General Musharraf ruled the country until 2008 and hold on to power unless he enjoyed the support of the most important ally in the War on Terror the US and Bush administration. After Musharraf's resignation in 2008, the direct military rule ended up with the democratically elected civil government. But this does not suggest that the military's role has vanished from the politics of the country but it yet possess a predominant role in the politics of Pakistan.

\section{Military in the Politics of Turkey: A Brief History}

Turkish army occupies a central role in the history of Turkish Republic since 1923. The Military is considered as the guardian of the basic principles of the republic such as the secularism, modernization, and westernization. In short, it is the guardian of the Kemalism. Among national institutions, the armed forces retain the public trust and respect the most. Since the demise of the founding leader of Turkish Republic and the end of one party rule, the army has directly intervened three times in the country's politics, in 1960, 1971 and in 1980. The first military coup was established against the backdrop of escalating tension between the government and opposition parties that intimated to erupt into a civil war. This coup removed the government and dissolved the parliament. Adnan 


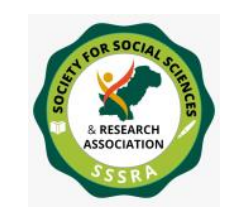

Pak. Journal of Int'L Affairs, Vol 4, Issue 4 (2021) $\quad$ Military and Politics: A Comparative Study ...

Menderes, the then prime minister was executed along with two other ministers, and several other members of the government were accused of other various crimes.

In the second coup of 1971, the government of Demirel was forced to step down after an ultimatum was issued and delivered by the army to the president which demanded the formation of a new government. Instead of direct rule, the military saw its role as one of the guiding the country's democratic process. Thus, after a consultation with the political parties, a new coalition government was formed with the help and support of the army. The perpetual disagreement and clashes between the left and right-wing factions resulted in another military intervention. The 1980's coup again was a response to the domestic political anarchy in which the new popularly elected government of PM Demirel was overthrown. Once more, the military claimed that it was their duty to prevent any civil war and to protect the Kemalist principles and the Republic itself.

Like Pakistan, beside these direct military interventions, the military has indirectly intervened in 1997 by forcing the civilian government to resign. And the July, 15, 2016 failed military coup is the most recent example of this continuous legacy. Apart from this, the military has been influential in Turkish political scene and dominated the security and foreign policy of the republic. The National Security Council (NSC) was the most powerful institution in this regard, which was absolutely dominated by the military until the first decade of 2000s. Since, the military's role has been more positive owing to the prospect of Turkey's track to the EU-membership. There seems a marriage between the civil and military leadership since the EU's decision to grant candidacy to Turkey in 1999. The recent change have already considerably reduced the power of the military in several of its long-standing authority in some civilian institutions (Ersel Aydinli, 2006, p. 81). But this does not mean that the Army no more play an important role in Turkish politics. The recent failed coup (July, 15, 2016) was carried by a considerably small group of Turkish troops. The government survived this time with a massive public support and the coup attempt was halted and the government regained the control soon.

\section{Causes of Military Tutelage in Politics: The Case of Pakistan}

An examination of the military intervention in politics can help us to build some general remarks with respect to the causes which gave way a professional military to take on an overtly political role. There are numerous reasons of military interventions in politics of Pakistan discussed in the following paragraphs.

\section{National Security}




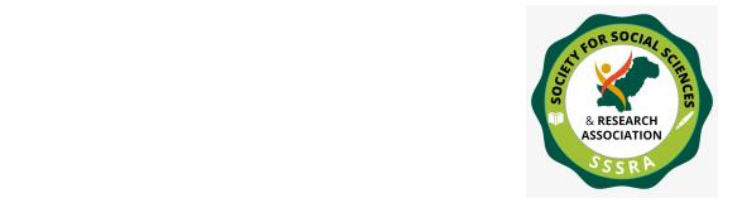

Military and Politics: A Comparative Study ...

The prominent cause of the military dominance in politics of Pakistan is the national security. The hostile regional environment in the early years of independence had made Pakistan very security conscious. On the one hand, India was the biggest threat to the newly created state of Pakistan which was carved out of the united India. One the other hand, Afghanistan was unwilling to accept Pakistan and voted against Pakistan's membership in the United Nations. Because, Afghanistan considers the Pashtun areas of Pakistan to be part of her territory and she does not recognize Durand Line as the international border between the two states.

On another front, the Communist Soviet Union was also a threat to the Pakistani state whose ideology was based on the religion of Islam. So, on this backdrop, there was a general consensus for maintaining a strong defense posture. Towards this end, a huge portion of the budget was allocated for the military, the country's participation in the defense pacts namely CENTO and SEATO and US military aid increased the capability of the army to purchase modern artilleries. This, in turn, boosted its efficiency and striking power up in the country. On the internal front, the parochial ethnic and regional politics helped military to gain an advantage over the civilian institutions.

Apart from this, strange geographical location of the country multiplied the national security threat. Pakistan was cut up into two separate parts namely East and West Pakistan, separated thousands miles from each other. And India, the most important considered enemy was dividing the two parts. Geographically, Pakistan was in a fragile position as a new born weak state and the military was believed to be the only messiah to protect it from dismemberment. (shah, 2014, p. 290). Thus, this security threat perception strengthened the hands of the military-bureaucratic forces. In particular, it gave way to the militarization of society, growth of the centralization of state power, and the curtailment of civil and political liberties in the name of national security.

\section{Weak Democratic Institutions}

Democratic institutions were not allowed to flourish since the country's independence. The then governor general abolished the first constituent assembly. The pioneer, first governor general and the leader of the nation Mohammad Ali Jinnah passed away one year after the independence. Liaqat Ali Khan, the first PM of Pakistan was assassinated after few years of independence. The first general elections were halted by the first military intervention. The civil democratic institutions and administrative institutions were unable to resolve the myriad problems the country was faced to. The legacy of administrative vacuums in Pakistan exists even today. The civilian setup frequently fails to cope with the natural as well as the man-made disasters in the country. And, the nation keep her eyes towards the military for the rescue in times of emergencies (Nasr, 2004, p. 


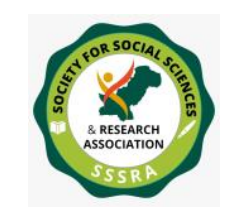

Military and Politics: A Comparative Study ...

199). Whenever the civil administration and institutions lacks the ability to satisfy the public demands, the military becomes active and intervenes in the political affairs of the state. We cannot know the hidden designs of General Ayub, the first military dictator, but apparently, the inefficiency of the democratic and civil institutions and administration paved the way for his disrespect for the civilian leadership and institutions.

Unfortunately, he was followed by his successor generals. Gen. Zia intervened when PM Bhutto was unwilling to arrange a re-election claimed by the opposition parties. Thus, these political parties started a campaign against Bhutto and the military, taking the advantage of the chaotic situation, intervened into the politics. Gen. Musharraf intervened in politics by toppling down Sharif's government, making an excuse of his failure to satisfy the public.

\section{Presence of Administrative Vacuum}

The first military coup in 1958 gave an opportunity to the civil service and the armed forces to directly run the government and administration by removing the weak democratic institutions and the political leadership from the scene. The military junta, with the introduction of certain reforms in economic and social structure tried to boost the pace of economic development up, but failed to abolish the outdated prevalent system altogether (Dawood, 2014, p. 287). As regards, the second phase of Ayub regime the military introduced an authoritarian political system with guided democracy in the country. Though this system ensured stability and continuity but on the expense of people's participation in the affairs of the country. The President became the center of all powers and was indirectly elected for a term of five years. The president was fully enjoying the support of the bureaucracy and the military. With the help of the 'Basic Democracies' system, he encouraged local development and gained public support for his introduced system. It was assumed that this system would produce a new generation of leaders who could better serve the political system in future but unfortunately failed to do so. The civil and military bureaucracy lacks the will and efficacy to sort out the long standing problems. Corruption, nepotism and lack of accountability exacerbated the already inefficient administrative setup.

\section{Massive Foreign Military Assistance and Modernization of the Military}

In the Cold War politics, the military of Pakistan became modernized and accumulated greater power through the help and assistance it received by joining the Western bloc. The modernization of the military is linked to the large extent with the foreign military and financial assistance it received through the security alliances established as part of the Cold War politics. The fate of Pakistan army was dramatically impacted in 1954 through the US Military Assistant Program, admission to the South East 


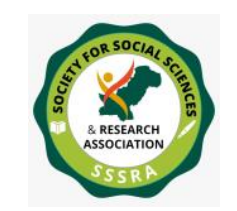

Pak. Journal of Int'L Affairs, Vol 4, Issue 4 (2021) $\quad$ Military and Politics: A Comparative Study ...

Asia Treaty Organization, and accession to the Central Treaty Organization a year later. The military acquired more confidence and efficiency as new and modern artillery arrived and training doctrine advanced (Ahmed, 2012, p. 411).

The military regimes in Pakistan have reaped a huge benefit from these economic and military assistance particularly from the United States. Ayub regime was bestowed in the name of the Security Alliances, Zia regime in the name of Afghan Jihad Campaign, and Musharraf regime in the name of War on Terror.

Most importantly, all these agreements related to the military assistance were worked out by the military leadership, not by the civilian governments, highlighting a pattern of absenteeism of the civilian check over the military affairs which probably continues to survive to this date. This massive foreign military assistance helped military to consolidate influence and act as a political actor to the extent where civilian governments were dependent on the military's well-organized manpower to correspond internal security situations (Rizvi, 2000, p. 156). Thus, an implicit understanding developed between the civilian and military bureaucracy to give strength to the existing order. By massive military assistance and trainings especially during 1950s, by the United States, the military became modernized, confident and took a prominent part in the fragile political arena in the country.

\section{Causes of Military Tutelage in Politics: the case of Turkey}

Military tutelage in Turkish politics has become robust due to numerous factors. Since the last decades of the Ottoman Empire and the process of the state-building, Turkish Armed Forces have been actively involved in the political sphere. Some of the prominent causes of the military dominance in the Turkish politics are highlighted in the following lines.

\section{Role of the Military as Founder and Guardian}

Turkish Armed Forces have a privileged position in terms of guarding the Turkish Republic and having some sort of political role owing to its historical context. As famous, the only institution that inherited from the Ottoman era to modern Turkey was the Army. In addition, the key role the military played in constructing a nation-state has been vindicating the military's role as the only guardian of the regime. Essentially, the army's political role has been justified by the military's responsibility to protect Turkey from domestic as well as foreign foes. The early republican leaders saw the military as the core pillar of the new regime. But they also acknowledged the fact that, the involvement of the military in politics worked against the unity as well as the discipline in the military 


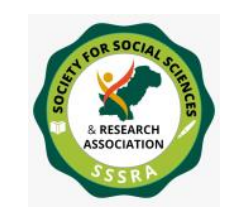

Pak. Journal of Int'L Affairs, Vol 4, Issue 4 (2021)

Military and Politics: A Comparative Study ...

(Nilufer, 2000, p. 117). In 1923, when Mustafa Kamal came to power in Turkey, one of his prime targets was to keep the military isolated from the direct participation in the politics.

Although separated from participating directly in the politics, it yet remained a crucial force for two reasons. First, the economic development plans, particularly the 1930s, were designed by the military considerations. Secondly, the military possessed the required skills and facilities. Thus, in the times of emergency, it sometimes assumed the control of the civilian administrative functions. Besides that, though the army was untouched to partisan politics, but it was used to support the one-party rule. The Republican People's Party instrumentalised the military to counter the reactionary forces and the oppositions (Szarejko, 2014, p. 144). Thus, this strengthened the army and provided them an upper hand in the political sphere in the country as opposed to the civilian democratic forces.

\section{Fear of Islamic Reactionism}

Another key factor for the predominant role of the Army in the political arena is the fear of Islamist's reaction. Islam has been considered the most weighed threat to the existence of the Kemalist ideology. The path going to the 1997 soft coup must be evaluated with this analysis. The general elections of 1995 resulted in the victory of an Islamist party, the Welfare Party which alarmed many civilian and military segments. People in these circles believed that the Welfare Party was an anti-secular and anti-democratic thus an enemy of the Kemalist principles.

This believe and claim that the basic principles of the regime were under threat, led to the uneven and unjust operations towards Islamists. In this crisis, the Turkish mainstream media played a crucial role by labelling the people with Islamic identities as the bone of contention and the internal security threat. Thus, as a result, measures were taken to expel the religious oriented people from the political scene. In countering the so called 'Islamic threat' within the lines of army, a body was formed named as the Western Working Group whose primary goal was to target the Islamists which were perceived as dangerous as the terrorists. (Momayezi, 1998, p. 19). Thus, the Army forced the then elected Prime Minister Najam udin Erbakan to resign and the Welfare Party was banned altogether from the political scene.

\section{Fear of Kurdish Separatism}

One of the key components contributed to the military tutelage in Turkish politics is the internal threats such as the Kurdish separatism. The Kurds are one of the most influential minorities in Turkey and form more than $22 \%$ of the population of Turkey. As they fell victim to the country's social and economic transformation period in the early 


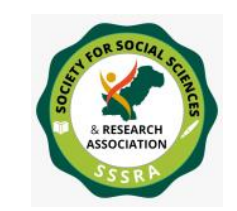

Military and Politics: A Comparative Study ...

years and thus resulted in an increased Kurdish ethnic and political consciousness. The resistance from the military and bureaucratic Kamalists elites to recognize the legitimate rights of Kurds, compelled them to select paths which were contradictory to the State (Karabelias, 2009, p. 66). Thus, the Kurdish separatist movement has been challenging the basic tenets and principles of the state and awakened the nationalists of the threat. To counter such threats, ideologies such as anti-communism, assertive secularism and most importantly Turkish nationalism have been promoted and encouraged by public education and media propaganda. Kuru (2012) aptly mentioned the oath that is recited by the students from grade one to four in all primary schools to promote secular nationalism in the country. The pledge emphasizes on proud of being a Turk, expression of the love for the homeland more than oneself, a staunch attachment to the Kemalist principles and emphasis on personal sacrifice to the being of the Turkish nation. (p.45)

In the early days of the Republic, Turkish nationalism and assertive secularism were imposed by the political civilian elites in the society. During the one party regime (1924-46), the army played an important role to spread and promote these policies. By promoting these policies, they succeeded in constraining and countering Islamists and Kurdish separatist elements.

\section{The Sole Actor of Modernization}

The Turkish military is the only institution which sustained through the Ottoman Empire to the modern Turkish state. Neither civilian bureaucracy nor any other institution survived but the army. From the late Ottoman period to the early Republican era, the modernization process has been led by the military. Military's this elite role is generally taken as the main cause of the military's involvement in the politics. Most of the time, the Turkish military, rely on its historical state-building role as the only actor to rescue the state from internal and external foes.

Indeed, the state-building process of Turkish State is based on the efforts of a group called 'enlightened elites' who think of themselves as the key actors in making a modern Westernized country. In this period, the masses were spared from the affairs of the new state and civilians were given less important roles. The modern Turkish Republic, from the inception, has not been focused on protecting the liberties of the individuals but it has been a metaphysical entity which was very proud of its great autonomy and innate value.

Similarities and Differences in the Nature of Military's Involvement in the Politics of Turkey and Pakistan:

\section{Direct vs. Indirect Rule}




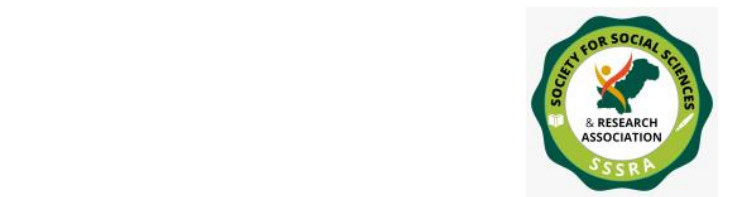

Pak. Journal of Int'L Affairs, Vol 4, Issue 4 (2021)

Military and Politics: A Comparative Study ...

Another difference between the military coups of Pakistan and Turkey is the direct and indirect nature of the military involvement and the guardian and ruler behavior of the military. In Turkey, almost all the military regimes have willingly withdrawn after a short period and confined their role to guardians in lieu of rulers. Another reason of their voluntary withdrawal can be cited as a result of development of strong civilian political institution. Political parties are good examples in this regard. Compare with Pakistani military, which remained in power for a longer period, Turkish military have not been holding on to power for long. The political institutions and parties in Pakistan have been much weaker than their counterparts in Turkey. The first military dictator General Ayub, directly ruled Pakistan from 1958-69 and was finally forced to resign by the massive public discontent. General Zia ul Haq, fiercely ruled Pakistan from 1977-88 and died in a plane crash. Similarly, General Musharraf ruled directly from 1999-2008 and was compelled to resign. And Finally, Turkey's alignment with international organizations and bodies such as the Council of Europe, the North Atlantic Treaty Organization, its aim to join the European Union, and the wish to integrate her economy into the global economic system have certainly constrained the military's ambitions to rule. While Pakistan's alignment was limited to the security Pacts in the region which provided the military an upper hand over the weak civilian institutions instead (Hale, 2018, p. 29).

\section{Safeguarding from Civil Wars}

One of the prominent excuses the military repeatedly has made prior to any intervention in Pakistan and in Turkey was to avert a predictable civil war created by the inexperienced and feeble parliaments and political forces. This is more evident in the Pakistani case than Turkish. The first military coup in Pakistan was attempted in the context of the disagreement between the Eastern and Western parts of Pakistan over the representation in the national assembly. The then army chief Zia ul Haque, in 1977, intervened in the politics to rescue Pakistan from the chaos created by the political parties after the results of the general elections. Similarly, General Musharraf, exercised his might to save the country from the corrupt and incompetent politicians.

On the other hand, in Turkey, similar examples can be quoted from the military interventions. The first military coup of 1960's occurred in the context of a mounting tension between the government and opposition forces which threatened to result in a civil war. In the second coup of 1971, the military recommended for a strong government that could sort out the chaotic situation prevalent in the country. And the 1980's coup again was a response to the domestic political anarchy in which the elected government of Demirel was forcefully overthrown. In the same line, the 1997 soft coup was staged by the army and this time the elected government of Erbakan was impelled to step down. The 


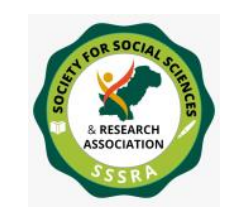

Pak. Journal of Int'L Affairs, Vol 4, Issue 4 (2021) $\quad$ Military and Politics: A Comparative Study ...

military was claiming sincerity to their desire to prevent a civil war and thus protect the Kemalist Republic.

\section{National Security and Secessionist Movements}

Another common factor in both the state with regards to the military tutelage is the national security within the state. National security in term of geography, has been the common tension in both Pakistan as well as in Turkey. In Pakistani case, the ethnic minorities feel debarred and the sense of manipulation by the central government and the biggest province 'Punjab' is prevalent among other provinces and ethnic nationalities since the independence. The outbreak of separatist and secessionist movements such as the East Pakistan (now Bangladesh), Pukhtunistan and Baluchistan have been seen time and again. The insurgency in Baluchistan is the strongest today and yet to be wiped out. On the other hand, the Kurdish minority has been a similar headache for the army with regards to national security of the country. The Turkish Armed Forces' attempt to tame the Kurdish question and wipe PKK out and its hard work to preserve the unity of the state narrate a similar story with Pakistan.

\section{Domination on Foreign and Security Policy}

Decision making in the foreign and security fields has always been dominated by the military in both the states since their independence. In the case of Turkey, these two areas have been occupied by the military elites even before the independence of the Republic. The department of National Security Council (NSC) in both Pakistan and Turkey have been dominated by military personnel. In the case of Turkey, there has been slight changes in the structure of the NSC and they have reduced the military representation in the NSC in recent years. Similarly, the National Security Council in Pakistan has always been predominant by the military. The decisions with respect to the national security and foreign policy have always been formulated and controlled by the military. With regards to unfriendly relations with the immediate neighbors like India and Afghanistan and internal political disorder, terrorism and insurgency such as in Baluchistan have given the military an excuse to dominate on the security and foreign policy decision making in the NSC.

\section{Conclusion}

Turkey and Pakistan have a similar history with regards to the military's tutelage in the politics. Turkey has experienced direct military coups thrice in its political history in 1961, 1970 and 1980 respectively. Apart from these direct involvement of the armed forces in the politics, popularly elected governments were forced to resign many a time by the military. The military tutelage in the political scene in the case of Turkey owes much to its historical role in the politics. In the pre-republican era, it was the military who played a 


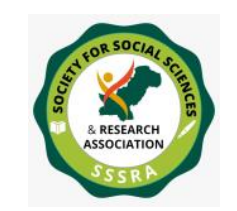

Pak. Journal of Int'L Affairs, Vol 4, Issue 4 (2021) $\quad$ Military and Politics: A Comparative Study ...

crucial role in the state-building process. Mustafa Kamal Pasha, the founder and father of the modern Turkey belonged to the military who remained the president of the republic almost fifteen years. This legacy was continued after his demise and the military performed a predominant role in the politics of the country. The military's superior role in Turkish society is owing to its characteristic of being the guardian of the Kemalist principles of Secularism, modernization and westernization.

Similarly, in Pakistan, the military holds a strong control in the political arena. Since the independence of the country, it has played a key role in the political fate of the nation. Pakistani military intervened directly in the politics in 1958, 1977 and 1999 by toppling the elected civilian governments and abrogating the constitution of the land. This military tutelage in the politics can be sighted as the result of several factors namely, the hostile environment in neighborhood, poor growth of the democratic institutions, presence of an administrative vacuum, the communist threat and the cold war bipolarity, and the massive foreign military assistance by the Western powers especially the US. In addition, they have certain features in common. In both the states, the military controls the foreign and security policy and it has an upper hand on the civil government in formulating the interior and foreign security policy. Contrarily, in the case of Pakistan, military has directly ruled in the country, but in Turkey, it has played a guardian role and an indirect rule.

Repeated military interventions weakened the civilian institutions, political parties and the democracy in both the states. But, since the early years of twenty-first century, the civil military relations have become stronger and the civilian institutions have gained an upper hand in the case of Turkey. All this was possible because of the leaning of the masses towards democracy and to fulfill the European Union conditionality for the membership which was mainly based on democratic principles to be fulfilled. The military's tutelage in the key states institutions such as the National Security Council has tamed. The foreign and security policy is not dominated by the armed forces anymore. The civilian government of Justice and Development Party which came to power in early 2000s, introduced several amendments to the constitution constraining the role of the military in the politics. By introducing these reforms, the new government gave ample rights to the minorities mainly the Kurdish ethnic minority which has posed a serious threat to the national security.

On the other hand, Pakistan has failed to constrain the military's tutelage in the political arena. In the case of Pakistan, the civilian institutions are not strong enough and lacks democratic will. There are deficiencies in our governance which can incite the military to play a proactive role in the political sphere. The civilian government needs to handle the administrative mess by giving more attention on transparency, accountability, 
responsibility and good governance. Moreover, the emergence of a free and stronger judiciary, an empowered independent media and a more democratically minded electorate can successfully restrict the military's involvement in politics. 


\section{References}

Ahmed, I. (2012). Pakistan the Garrison state; origin, evolution, consequences 1947-2011. London: Oxford university press.

Ali, M. (2008). Military control in Pakistan; the parallel state. london: Routledge.

Burak, B. (2011). The Role of the Military in Turkish Politics: To Guard Whom and From What? European journal of economic and political studies, 4(1), 143-169.

Dawood, M. (2014). the causes of military intervention in politics; a case study of Pakistan and Bangladesh. European Scientific Journal, 28-293.

Ersel Aydinli, N. A. (2006). The Turkish Military's March toward Europe. Foreign Affairs, 85(1), 77-90.

Hale, W. (2018). The Turkish military in politics, and the attempted coup of 15-16 July 2016. Iktisat ve Sosyal Bilimlerde Güncel Araştırmalar, 2(1), 7-41.

Karabelias, G. (2009). The Military Institution, Atatürk's Principles, and Turkey's Sisyphean Quest for Democracy. Middle Eastern studies, 45(1), 57-69.

Kuru, A. T. (2012). The Rise and Fall of Military Tutelage in Turkey: Fears of Islamism, Kurdism, and Communism. Insight Turkey, 14(2), 37-57.

Momayezi, N. (1998). Civil-military relations in Turkey. International journal on world peace, 15(3), 3-28.

Nasr, V. (2004). military rule, islamism and democracy in Pakistan. the middle east ournal, 58(2), 195-209.

Nilufer. (2000). Civil-military relations in Turkey. Turkish Studies, 1(1), 107-127.

Rizvi, H. A. (2000). Military, state and society in Pakistan. London: Palgrave Macmillan.

Rizvi, H. A. (2015). The military and Pakistan's political and security disposition. Asia Policy, 19, 147-151. 
shah, A. (2014). The Army and Democrac: military politics in Pakistan. london: Harvard University Press.

SZAREJKO, A. A. (2014). The Soldier and the Turkish State: Toward a General Theory of Civil-military Relations. PERCEPTIONS: Journal of international Affairs, 19(2), $139-158$. 